\begin{tabular}{c|l} 
Notaice & $\begin{array}{l}\text { e-ISSN: } 2655-9404 \\
\text { DOI: } 10.20473 / \text { ntr.v1i2.9759 }\end{array}$ \\
Vol. 01 No. 2, Oktober 2018 & .
\end{tabular}

Article history: Submitted 3 October 2018; Accepted 10 October 2018; Available online 15 October 2018.

\title{
Perkawinan Sirri di Desa Kalisat Kecamatan Rembang Kabupaten Pasuruan
}

\author{
Avisena Aulia Anita, Felisa Haryati dan Diah Astri Ellisa \\ avisenaauliaanita@gmail.com \\ Universitas Airlangga
}

\begin{abstract}
The marriage law was formed to regulate the life of a perfect, happy and eternal human life in a household. So that in carrying out marriage must also be based on the marriage rules that apply in Indonesia, namely Act No. 1 of 1974, which must be valid based on religious and state law. If it is not done legally, the impact will be on the woman (wife) and her offspring, in addition to it in the event of a divorce, it does not have the legal power to claim any rights, because it is only legitimate in the eyes of religion, for example "Nikah Sirri". Because of the many practices of nikah sirri, it is fitting that there should be further supervision and more explanation regarding nikah sirri. One of the authors raised is the practice of nikah sirri that occurs in an area in Pasuruan. The purpose of this writing, to help provide an overview and reality of the impact of the nikah sirri, supported by field research and conceptual approaches to facilitate this writing.
\end{abstract}

Keywords: Marriage; Law; Sirri; Village; Kalisat.

\begin{abstract}
Abstrak
Undang-Undang perkawinan dibentuk untuk mengatur pergaulan hidup manusia yang sempurna, bahagia dan kekal didalam suatu rumah tangga. Sehingga dalam melaksanakan perkawinan pun harus berdasarkan menurut aturan perkawinan yang berlaku di Indonesia yaitu UU No 1 Tahun 1974, dimana harus sah berdasarkan hukum agama dan hukum negara. Apabila tidak dilakukan secara sah maka dampaknya adalah pada pihak perempuan (istri) dan keturunannya, selain it apabila terjadi perceraian, maka tidak memiliki kekuatan hukum untuk menuntut suatu hak apapun, karena hanya sah di mata agama, misalnya "Kawin Sirri". Karena banyaknya praktik kawin sirri, maka sudah sepatutnya perlu ada pengawasan lebih lanjut dan penjelasan lebih mengenai kawin sirri. Salah satu yang penulis angkat yaitu mengenai praktik perkawinan sirri yang terjadi di suatu daerah di Kabupaten Pasuruan. Tujuan penulisan ini, untuk membantu memberikan gambaran serta realita yang ada akan dampak dari perkawinan sirri tersebut, dengan didukung penelitian lapang serta pendekatan konseptual untuk memudahkan penulisan ini.
\end{abstract}

Kata Kunci: Nikah; Hukum; Sirri; Desa; Kalisat.

\section{Pendahuluan}

Indonesia merupakan negara majemuk yang memiliki suku bangsa, adat, agama serta bahasa yang bermacam-macam di tiap daerahnya. Hal ini disebabkan oleh luasnya negara Indonesia yang terdiri dari banyak pulau baik itu pulau yang besar maupun pulau kecil dari Sabang sampai Merauke sehingga tumbuh beranekaragam, dalam kehidupan sehari-hari setiap daerah memiliki corak dan kebiasaan serta adat yang berbeda-beda seperti dalam hal tata cara beragama, tata 
cara perkawinan, hingga tata cara penyelesaian masalah. Dalam hal perkawinan, di Indonesia telah diatur dalam Undang-Undang No 1 Tahun 1974 Tentang Perkawinan, tetapi dalam kenyatannya masih banyak masyarakat yang memakai tata cara perkawinan dengan adatnya masing-masing dan tidak sesuai dengan tata cara agama yang sebenarnya tidak diakui secara sah oleh negara. Dewasa ini bahkan sering terdengar praktik pernikahan yang disebut dengan nikah sirri atau lebih dikenal dengan nikah dibawah tangan karena tidak dicatat secara resmi oleh KUA atau perkawinan yang dilangsungkan bisa jadi tanpa adanya wali yang sah dari pihak wanita.

Praktik pernikahan sirri merupakan dampak adanya perubahan budaya di dalam masyarakat yang semakin modern dimana masyarakat yang tidak memiliki pendidikan tinggi menempuh cara tersebut untuk memenuhi kebutuhan ekonomi hingga melupakan nilai-nilai suci dalam agama maupun dalam perkawinan itu sendiri yang dalam undang-undang dikatakan "merupakan ikatan lahir batin antara seorang pria dan seorang wanita sebagai suami istri dengan tujuan membentuk keluarga atau rumah tangga yang bahagia dan kekal berdasarkan Ketuhanan Yang Maha Esa”. Degradasi kesakralan dan tujuan dari suatu perkawinan dengan praktik pernikahan sirri, contohnya adalah pada Desa Kalisat, Dusun Krajan, Kecamatan Rembang, Kabupaten Pasuruan, Jawa Timur, yang dilakukan oleh Rusna yang terungkap pada bulan Maret 2012. Dimana Rusna mengatakan “mau nikah sirri berulang kali karena pertimbangan ekonomi, apabila ditinggalkan suami-suami sebelumnya, langsung nikah sirri lagi dengan pria lain". ${ }^{1}$

Permasalahan di Desa Kalisat, Kabupaten Pasuruan, Jawa Timur ini merupakan dampak negatif dari kurangnya pendidikan pada masyarakat desa tersebut sehingga masyarakat mau melakukan nikah sirri berulang kali dengan banyak pria dengan alasan faktor ekonomi yang tidak mencukupi, padahal sebenarnya dengan dilangsungkanya praktik pernikahan sirri tersebut juga keadaan ekonomi dari para pelakunya tidak banyak berubah dan cenderung sama saja belum mencukupi. Jika

${ }^{1}$ Http://nasional.inilah.com/read/detail/1839431/inilah-perempuan-enam-kali-nikah-sirri\#.VHBkyvmUdDa, diakses pada22 November 2014. 
masalah praktik pernikahan di Desa Kalisat terus dilakukan maka praktik tersebut jadi budaya dan akan terjadi praktik pernikahan yang tidak sesuai dengan tujuannya baik dari sisi agama maupun dari sisi perundang-undangan dan para pelakunya cenderung melakukannya berulang-ulang seakan-akan perkawinan adalah suatu hal yang biasa saja dan dilakukan dengan tujuan memperbaiki ekonomi.

Pendidikan dan kebudayaan adalah sesuatu yang sangat berkaitan erat antara satu dengan yang lainnya yaitu dalam hal pengembangan nilai. Apabila suatu masyarakat berpendidikan yang baik maka akan timbul kebudayaan yang baik juga sehingga nilai-nilai yang dihasilkan berbanding lurus dengan nilai moral maupun ajaran agama atau kepercayaan yang dianut oleh tiap-tiap masyarakatnya. Oleh karena itu, dari pemaparan diatas saya mengangkat tulisan yang berkenaan dengan praktik pernikahan sirri yang dilakukan oleh masyarakat dengan judul "Praktik Pernikahan Sirri di Desa Kalisat, Kabupaten Pasuruan, Jawa Timur”.

\section{Rumusan Masalah}

1. Bagaimana praktik perkawinan sirri di Desa Kalisat, Kecamatan Rembang, kabuaten Pasuruan?

2. Bagaimana dampak dari perkawinan sirri tersebut bagi masyarakat sekitar?

\section{Definisi Perkawinan}

Seperti yang telah diketahui bahwa pada umumnya perkawinan itu sebagai suatu perbuatan atau tindakan yang sakral yang mana terjadi sekali seumur hidup sehingga harus dilaksanakan dengan bijak, baik, dan ini merupakan suatu hubungan yang berkaitan antara manusia dan tuhan. Perkawinan merupakan ikatan lahir batin antara seorang pria dan seorang wanita dengan tujuan membentuk suatu keluarga yang sakinah, mawadah, warahmah, yang dilakukan atas dasar saling mencintai, satu kepercayaan serta kewarganegaraan Indonesia dan mengikuti hukum yang berlaku di Indonesia. Perkawinan menjadi sebuah kebutuhan hidup seluruh umat manusia dari dahulu hingga sekarang, selain untuk memiliki keturunan, perkawinan juga sebagai salah satu perbuatan hukum, oleh karena itu tentu akan mempunyai akibat 
hukum, oleh karena ada akibat hukum inilah tentu memiliki hubungan dengan sah atau tidaknya suatu perbuatan hukum (perkawinan).

Apabila suatu perkawinan menurut hukum tidak sah, maka anak yang lahir dari perkawinan tersebut dianggap tidak sah sehingga ketika terjadi perceraian tidak memiliki kekuatan hukum untuk menuntut suatu hak apapun. Oleh karenanya setiap orang yang melangsungkan perkawinan agar dianggap sah menurut hukum dan agamanya masing-masing maka harus dilaksanakan menurut prosedur yang telah ditetapkan oleh peraturan yang berlaku. Definisi perkawinan menurut UU No 1 Tahun 1974 tentang perkawinan, pasal 1 memberikan definisi sebagai berikut.

"perkawinan adalah ikatan lahir dan batin antara seorang pria dan seorang wanita sebagai suami istri dengan tujuan membentuk keluarga (rumah tangga) yang bahagia dan kekal berdasarkan Ketuhanan Yang Maha Esa". 2

Undang-undang perkawinan dibentuk bertujuan untuk mengatur pergaulan hidup yang sempurna, bahagia dan kekal didalam suatu rumah tangga. Undangundang ini bersifat nasional, unikum (satu kesatuan hukum) karena sebelum lahirnya undang-undang ini terdapat berbagai macam peraturan perkawinan yang pernah berlaku di Indonesia dan juga menampung prinsip-prinsip dan memberikan landasan hukum perkawinan yang selama ini menjadi pegangan dan telah berlaku bagi berbagai golongan WNI. Undang-undang ini juga mengandung prinsip atau asas mengenai perkawinan dan segala sesuatu yang berhubungan dengan perkawinan yang telah disesuaikan dengan perkembangan zaman. Karena kedinamisannya itulah diharapkan undang-undang perkawinan ini bisa mengakomodir dan mengatur lebih lanjut tentang perkawinan. Adapun asas yang tercantum dalam undang-undang ini adalah sebagai berikut :

1. Tujuan perkawinan adalah membentuk keluarga yang bahagia dan kekal. Untuk itu suami istri perlu saling membantu dan melengkapi agar masing-masing dapat mengembangkan kepribadiannya, membantu dan mencapai kesejahteraan spiritual dan materiil.

2. Dalam UU ini dinyatakan bahwa suatu perkawinan adalah sah bila dilakukan

2 Undang-Undang No 1 Tahun 1974 Tentang Perkawinan. 
menurut hukum agama dan kepercayaan masing-masing serta perkawinan itu dicatatkan menurut peraturan perundang-undangan yang berlaku.

3. Asas monogami, asas ini ada pengecualian, apabila dikehendaki oleh yang bersangkutan karena hukum dan agama mengizinkan seorang suami dapat beristri lebih dari satu. Namun demikian, perkawinan seorang suami dengan lebih dari seorang istri meskipun hal itu dikehendaki oleh pihak yang bersangkutan, hanya dapat dilakukan apabila dipenuhi sebagai persyaratan tertentu dan diputuskan oleh pengadilan.

4. Prinsip calon suami istri harus telah masak jiwa dan raganya untuk dapat melangsungkan perkawinan agar supaya dapat mewujudkan tujuan perkawinan secara baik tanpa berakhir pada perceraian dan mendapat keturunan yang sehat.

5. Karena tujuan perkawinan adalah membentuk keluarga yang bahagia, kekal dan sejahtera maka undang-undang ini menganut prinsip mempersulit terjadinya perceraian.

6. Hak dan kedudukan suami istri adalah seimbang dengan hak dan kedudukan suami baik dalam kehidupan rumah tangga maupun dalam pergaulan masyarakat sehingga dengan demikian segala sesuatunya dalam keluarga dapat dirundingkan dan diputuskan oleh suami istri. ${ }^{3}$

Perkawinan merupakan suatu perjanjian suc dalam membentuk keluarga dan antara seorang laki-laki dan perempuan dimana perjanjian itu merupakan perbuatan yang dikehendaki oleh masing-masing pihak dan berdasarkan agama. ${ }^{4}$ Dalam kepustakaan, perkawinan ialah aqad yang menghalalkan pergaulan dan membatasi hak dan kewajiban serta tolong menolong antara seorang laki-laki dan perempuan yang antara keduannya belum mukhrim. Menurut hukum islam nikah adalah aqad yang mengandung kebolehan untuk bersetubuh dengan lafadz atau terjemahan dari kata-kata tersebut jadi maksud pengertian tersebut adalah apabila seorang laki-laki dan perempuan sepakat untuk membentuk suatu rumah tangga maka hendaknya

3 Martiman Prodjohamidjojo, Hukum Perkawinan Indonesia, (Legal Center Publishing 2007).[3].

4 Sayuti Thalib, Hukum Kekeluargaan Indonesia, (Internas 1981).[47]. 
keduanya melakukan aqad nikah lebih dulu. ${ }^{5}$

\section{Prosedur Pelaksanaan Perkawinan Secara Umum maupun menurut Hukum Islam}

Aqad nikah tersusun dari pada Sighot (Susunan Kata) yang berisi Ijab yakni penyerahan dari pihak pertama dan Qabul yakni penerimaan dari pihak kedua atas pertalian nikah yang dimaksud. Perkataan dari pihak pertama : "saya nikahkan engkau dengan anak saya bernama...dengan mas kawin” kemudian diterima oleh pihak kedua : "saya terima nikah...dengan mas kawin ...tunai / hutang"6. Aqad nikah ialah perjanjian antara wali nikah dari mempelai wanita dengan mempelai laki-laki dimuka umum, paling sedikit dua orang saksi yang mencukupi syaratsyarat menurut syariat islam. Aqad nikah terdiri atas : ${ }^{7}$

1. Ijab yakni penyerahan mempelai wanita oleh walinya kepada mempelai lakilaki;

2. Qobul yakni penerimaan mempelai wanita oleh mempelai laki-laki.

Ijab itu harus segera dijawab dengan qabul secara langsung dan tidak raguragu. Tidak tertibnya aqad nikah menurut peraturan syariah dapat mengakibatkan tidak sahnya perkawinan.oleh karena itu tertibnya suatu aqad perkawinan akan dianggap sah jika diselenggarakan :

a. Menurut hukum masing-masing agama dan kepercayaannya;

b. Secara tertib menurut hukum syariah (bagi yang beragama islam);

c. Dicatat menurut perundang-undangan dengan dihadiri oleh pegawai pencatat nikah.

Untuk orang Indonesia dari agama manapun pencatatan dilakukan oleh pegawai pencatat nikah dari kantor catatan sipil sedang untuk yang beragama islam pencatatan dilakukan oleh pegawai pencatat nikah, talaq, rujuk, dari KUA.

\footnotetext{
5 Al-Qur'an Surah An-Nisa : 3.

${ }^{6}$ Martiman, Op Cit.[9].

${ }^{7}$ Martiman Prodjohamidjojo, Hukum Perkawinan dalam Tanya Jawab, (Legal Center Publishing 2007).[71].
} 
Dalam undang-undang perkawinan dianut asas monogami yaitu suatu perkawinan antara seorang pria dengan wanita sebagai seorang istri dan seorang istri hanya boleh mempunyai seorang suami. Akan tetapi undang-undang perkawinan itu juga memberikan kemungkinan seorang pria mempunyai lebih dari seorang istri (berpoligami) dengan sejumlah syarat dan ketentuan yang harus dipenuhi. Membina suatu rumah tangga bukanlah perkara mudah ditengah perjalanan pasti ada satu dari beberapa hal yang menjadi permasalahan pemicu perceraian. Meskipun perceraian merupakan jalan terburuk dan terakhir yang akan dicoba tapi sudah sepantasnya kedua calon mempelai mengantisipasi terlebih dahulu. Salah satu perlindungan atas hal terburuk yang kemungkinan terjadi dalam perkawinan yaitu adalah dengan dibuatnya suatu perjanjian perkawinan. Calon mempelai dapat menyelenggarakan perjanjian perkawinan sebelum perkawinan dilangsungkan.

\section{Syarat Perkawinan Secara Umum Maupun Menurut Hukum Islam}

Seperti yang telah dijelaskan diatas perkawinan merupakan suatu perbuatan hukum sehingga dari perkawinan akan timbul hubungan hukum antara suami istri danjika kemudian dengan lahirnya anak-anak, maka menimbulkan hubungan hukum antara orang tua dengan anak-anak mereka. Oleh karena itu sebelum dilaksanakan suatu perkawinan, kedua calon mempelai harus memenuhi syarat-syarat disamping ketentuan hukum masing-masing agama, undang-undang perkawinan menentukan syarat-syarat perkawinan sebagai berikut :

1. Perkawinan harus didasarkan atas persetujuan kedua calon mempelai. Jadi dalam perkawinan ada kebebasan kehendak dan dihindari adanya unsur paksaan.

2. Seseorang yang belum mencapai umur 21 tahun harus mendapat izin dari orang tuanya. Sedangkan apabila menyimpang dari umur yang disebutkan diatas, maka dapat meminta dispensasi dari pengadilan atau pejabat lain yang ditunjuk oleh kedua orang tua pihak perempuan maupun pihak lakilaki (dalam KUHPerdata ditentukan untuk laki-laki sudah mencapai umur 18 tahun dan untuk perempuan sudah mencapai 16 tahun. Tiap-tiap negara dapat 
mennetukan batas umur untuk kawin. Ketentuan itu menegaskan bagi mereka yang berumur 21 tahun keatas, tidak memerlukan izin dari orang tuanya).

3. Jika salah satu dari kedua orang tua meninggal dunia atau tidak mampu menyatakan kehendaknya, izin cukup diperoleh dari orang tua yang mampu menyatakan kehendaknya.

4. Jika kedua orang tua meninggal dunia atau tidak mampu menyatakan kehendaknya, izin diperoleh dari wali orang yang memeliharanya atau keluarga yang mempunyai hubungan darah dalam garis keturunan lurus keatas selama mereka masih hidup dan dalam keadaan dapat menyatakan kehendaknya.

5. Dalam hal terdapat perbedaan pendapat diantara mereka atau jika seseorang atau lebih diantara mereka tidak menyatakan pendapat. Maka pengadilan dalam daerah hukum tempat tinggal orang yang akan melangsungkan perkawinan atas permintaan orang tersebut dapat memberikan izin setelah lebih dahulu mendengar orang-orang yang disebut diatas.

6. Hal-hal yang disebutkan diatas berlaku sepanjang hukum masing-masing. Pencatatan perkawinan bagi mereka yang melangsungkan pekawinan menurut dalam Undang-Undang No 32 Tahun 1954 Tentang Pencatatan Nikah, Talaq, dan Rujuk. Bagi mereka yang melangsungkan perkawinannya menurut agama lain selain agama islam serta kepercayaan dilakukan oleh pegawai kantor pencatatan sipil yang dimaksud dalam berbagai perundang-undangan mengenai pencatatan perkawinan. Perkawinan dilangsungkan dengan tata cara sebagai berikut :

1. Perkawinan dilangsungkan setelah hari ke 10 sejak pengumuman kehendak perkawinan oleh pegawai pencatat nikah;

2. Tata cara perkawinan dilakukan menurut hukum masing-masing agama dan kepercayaannya;

3. Penyelenggaraan perkawinan dilakukan oleh pegawai pencatat nikah dengan dihadiri oleh dua orang saksi;

4. Setelah penyelenggaraan tata cara perkawinan selesai, kedua mempelai menandatangani atau membubuhkan cap jempol pada akta perkawinan yang kemudian disusul penandatanganan pegawai pencatat nikah dan terakhir di tandatangani pula oleh wali nikah atau kuasa yang mewakilinya. ${ }^{8}$

\footnotetext{
8 Martiman, Loc.cit.
} 
Dengan penandatanganan akta perkawinan maka perkawinan tersebut telah tercatat resmi. Akta perkawinan ialah akta yang dibuat oleh pejabat pencatat nikah yang membuktikan bahwa telah teerjadi perkawinan dan memuat tentang identitas kedua calon mempelai, saksi, wali, persetujuan kedua calon mempelai, izin-izin, dispensasi (pengecualian), dan juga perjanjian perkawinan (bila ada). Akta nikah dibuat rangkap dua, helai pertama disimpan pada panitera pengadilan, sedangkan kutipan akta perkawinan diberikan kepada suami istri masing-masing. Untuk melaksanakan perkawinan kedua calon mempelai harus terlebih dahulu memenuhi syarat yang telah disebutkan diatas tidak terlepas juga syarat dari agama dan kepercayaan masing-masing mempelai.

Suatu perkawinan haruslah sah dimata hukum juga dimata agama, sehingga jika dikemudian hari terjadi sesuatu hal yang tidak di inginkan perkawinan tersebut dapat dipertanggung jawabkan baik secara hukum maupun dihadapan agama dan tidak menimbulkan kerugian untuk pihak manapun. Untuk surat yang terkait dengan perkawinan pegawai pencatat nikah harus melakukan penelitian terhadap surat-surat yang diajukan calon mempelai laki-laki maupun perempuan, sebelum aqad nikah dilangsungkan surat-surat tersebut berkaitan dengan perkaiwnan yang akan dilangsungkan. Surat-surat yang harus diteliti seperti :

a. Keterangan lurah / kepala desa yang menyatakan identitas : nama, tempat, dan tanggal lahir serta nama orang tua;

b. Keterangan mengenai nama, agama / kepercayaan, pekerjaan dan tempat tinggal, nama serta tempat tinggal orang tua calon mempelai;

c. Izin tertulis dari orang tua / izin pengadilan jika para calon belum mencapai umur 21 tahun;

d. Dispensasi pengadilan / pejabat yang ditunjuk bagi calon mempelai dibawah umur untuk kawin;

e. Surat kematian istri / suami yang terdahulu / surat cerai (akta perceraian);

f. Izin tertulis dari pejabat yang ditunjuk oleh menteri pertahanan / keamanan atau panglima TNI apabila seorang calon mempelai atau kedua-duanya anggota TNI;

g. Surat kuasa otentik / dibawah tangan yang disahkan oleh pegawai pencatat nikah, apabila salah satu calon mempelai atau keduanya tidak dapat menghadiri sendiri karena ada alasan yang penting, sehingga mewakilkannya kepada orang lain; 
Setelah semua persyaratan telah dipenuhi oleh kedua calon mempelai, barulah perkawinan dapat dilangsungkan tanpa satu hambatan yang berarti. Perkawinan yang dilangsungkan dengan memenuhi semua persyaratan sudah pasti sah dimata hukum dan dimata agama serta juga dapat dipertanggung jawabkan kelangsungannya dihadapan hukum dan agama.

\section{"Kawin Kontrak" Sebagai Kebiasaan yang di Legalkan atau Perbuatan Melawan Hukum sebagai Modus "Kawin Sirri”.}

Kawin kontrak diyakini banyak kalangan menimbulkan mudharat yang lebih besar ketimbang maslahat, utamanya dipihak perempuan dan anak. Dianggap bahwa kawin kontrak menjadi pertentangan diantara agama, hukum dan realitanya. Beberapa kasus seperti dikawasan puncak pernah memiliki daya tarik baru selain pesona keindahan alamnya, kawasan tersebut sempat dikenal sebagai lokasi praktik kawin kontrak baik yang dilakukan pejabat, maupun masyarakat biasa pada umumnya melalui bantuan biro jodoh atau makelar yang menawarkan jasanya untuk melakukan kawin kontrak. Dengan mengambil wanita yang berasal dari lokalisasi / WTS dengan berkedok asal dari pesantren yang mana dilakukan melalui sebuah kontrak dan mahar perkawinan yang telah ditentukan dan kebanyakan modus "Kawin Kontrak" ialah "Kawin Sirri” sehingga meskipun hal ini tidak dilegalkan secara hukum tetapi sah menurut hukum agama (islam).

Praktik kawin kontrak sendiri di Indonesia diperkirakan sudah berlangsung lama. Di dalam agama islam, menurut Abdus Salam Nawawi, kawin kontrak dikenal dengan istilah kawin Mut'ah. Sebenarnya kawin mut'ah sudah terjadi sejak zaman Rasulullah hanya saja dimasa itu dilakukan karena keadaan terdesak seperti pada saat terjadi perang, banyak para pria yang menjadi korban perang dan para wanita kehilangan suami mereka sehingga diperbolehkan melakukan kawin kontrak dan pada saat itu kondisi berbeda karena dalam keadaan "darurat" saat itu pula rasulullah mengizinkan tentaranya yang terpisah jauh dari istrinya untuk melakukan kawin mut'ah dari pada nantinya melakukan penyimpangan. Namun, kemudian rasulullah mengharamkannya ketika melakukan pembebasan kota mekkah pada tahun $8 \mathrm{H}$ / 
630 M. hal inilah yang kemudian terbawa hingga masa modern dan masyarakat menganggap tak masalah melakukan hal itu yang pada kenyataannya zaman dahulu dan sekarang itu berbeda.

Kebanyakan pria melakukan ini karena nafsu semata / hasrat birahi yang sebenarnya melakukan kawin kontrak sebagai modus dianggap sama dengan "Kawin Sirri” yang meskipun tidak sah secara negara tapi sah menurut agama sehingga, itu menjadi sebuah alasan utama bagi mereka untuk melakukan yang justru menimbulkan kerugian bagi pihak wanita. Selain itu secara prinsip perkawinan adalah kontrak. Namun, perkawinan bukan kontrak semata, perkawinan merupakan kontrak suci karena berjanji didepan wali, saksi dan juga didepan allah, bahwa ia akan memperlakukan pasangannya dengan baik. Sementara itu menurut Abdul Moqsith Ghazali, kepala Madrasah Ushul Fiqh Progresif Wahid Institute melihat kawin kontrak dari aspek akibat. Meskipun kawin kontrak merujuk pada AlQur'an dan Hadist, tapi dalam konteks saat ini harus dipertimbangkan efeknya baik positif dan negatif. Selain itu hal serupa juga ditentang oleh Quraish Shihab bahwa perkawinan haruslah langgeng dan didasari atas cinta, sementara kawin kontrak sifatnya tidak langgeng sehingga bertentangan dengan filosofi tujuan perkawinan.

Mut'ah/zuwaaj muaggot/kawin kontrak dimana waktunya terserah pada perjanjian yang disetujui oleh kedua belah pihak. Boleh satu tahun, satu bulan, satu hari, bahkan ada yang satu jam dan boleh sekali main. Sedang batas perempuan yang di mut'ah terserah si laki-laki boleh berapa saja terserah kekuatan dan minat si laki-laki. mereka tidak saling mewarisi bila salah satu pelakunya mati, meskipun masih dalam waktu yang disepakati. Juga tidak wajib memberi nafkah dan tidak wajib memberi tempat tinggal. Mut'ah dilakukan tanpa wali dan saksi. Begitu pula tanpa talaq tetapi habis begitu saja pada akhir waktu yang disepakati. Pelakunya boleh perjaka atau duda, perawan atau janda, namun pada praktiknya adalah janda / duda bahkan yang sudah punya istri dan dalam fatwa Khumaini seseorang boleh melakukan mut'ah sekalipun dengan WTS. Adapun tempatnya boleh dimana saja, 
baik di dalam rumah maupun di luar rumah. ${ }^{9}$ Lalu bagaimana status perkawinan apabila terlanjur terjadi, apa akibat hukum yang terjadi seperti pewarisan dan soal anak. Menurut Quraish Shihab:

"Di negara yang mayoritasnya beraliran Syiah dimana aliran yang menerima konsep mut'ah seperti iran, status perkawinanya diakui bahkan status anak diakui, sehingga otomatis memungkinkan untuk menjadi ahli waris".

Lalu bagaimana dengan di Indonesia, tidak ada akibat hukum apapun dalam perkawinan kontrak pasalnya perkawinan seperti ini adalah perzinahan. Pihak perempuan dalam kawin kontrak tidak lebih dari sekedar komoditas seks. Kawin kontrak hanya dijadikan alasan dengan menggunakan kedok agama untuk melaksanakan prostitusi terselubung atau bahkan perdagangan wanita dengan kedok "Kawin Sirri”. Selain itu nasib anak hasil kawin kontrak tidak akan berbeda jauh dengan nasib sang ibu. Hampir pasti si anak tidak akan mendapatkan warisan apapun, setelah selesai masa kontrak maka anak akan sepenuhnya menjadi tanggung jawab sang ibu (perempuan). Soal perempuan sebagai pihak yang memiliki potensi dirugikan lebih besar inilah tidak ada satupun perempuan yang tidak ingin, kecuali terpaksa perkawinan langgeng. Itu sebabnya jika ada orang tua yang dilamar anak gadisnya maka ia akan berpikir berulang kali, untuk menerimanya. Hal ini berhubungan juga dengan stereotip yang berkembang bahwa perempuan itu ibarat kembang api, yang setelah dinyalakan lalu dibuang.

Lalu muncul pertanyaan bagaimana dengan aturannya. Ketiadaan aturan hukum yang mengatur kawin kontrak dengan segala akibatnya inilah yang membuat pengawasan kasus semacam ini lemah "hukum itu sendiri yang melemahkannya", sehingga beberapa pihak mendesak agar dilakukannya pembaharuan dalam hukum perkawinan, ketiadaan pasal yang mengatur soal kawin kontrak mengakibatkan aparat penegak hukum menggunakan jerat hukum lain. ${ }^{10}$

\footnotetext{
${ }^{9}$ http ://www.albayyinat.net/mutaht.html, diakses pada 22 November 2014, 18:27 WIB.

${ }^{10}$ http://www.hukumonline.com/berita/baca/holl5650/kawin-kontrak-antara-agama-hukum-dan-realita, diakses pada 22 November 2014, 18:45 WIB.
} 


\section{Metode Penelitian}

Metodologi deskriptif kualitatif adalah merupakan penelitian yang termasuk dalam jenis penelitian kualitatif. Tujuan dari penelitian ini adalah mengungkap fakta, keadaan, fenomena, variable dan keadaan yang terjadi saat penelitian berjalan dan menyuguhkan apa adanya. ${ }^{11}$ Adapun yang dimaksud dengan penelitian kualitatif yaitu penelitian yang bermaksud untuk memahami fenomena tentang apa yang dialami subyek penelitian secara holistik dan dengan cara deskripsi dalam bentuk kata-kata dan bahasa. Pada suatu konteks khusus yang alamiah dan dengan memanfaatkan metode ilmiah. ${ }^{12}$

\section{Pendekatan Penelitian}

Dalam penelitian yang peneliti lakukan adalah menggunakan metode pendekatan lapangan sosial yang semi otonom, yaitu dimana masyarakat di Desa Kalisat hidup menciptakan aturan-aturan internal yang berlaku dalam lingkungan mereka sendiri. dimana mendorong warganya untuk mengikuti aturan-aturan tersebut. Aturan-aturan internal yang dimaksud adalah aturan mngenai praktik perkawinan sirri yang dilakukan oleh masyarakatnya terutama kaum wanita yang merupakan janda. Penelitian yang dilakukan peneliti ini berdasarkan aturan-aturan internal praktik perkawinan sirri di Desa Kalisat yang merupakan peraturan tidak tertulis dan lama kelamaan telah menjadi budaya di masyarakat Desa Kalisat. Hal tersebut dapat dilihat dari bagaimana pemuka agama di desa setempat yang tidak mempermasalahkan praktik perkawinan sirri tersebut sehingga peraturanperaturan mengenai praktik perkawinan dianggap tidak bertentangan dengan agama dan masyarakatnya, menjalankan praktik tersebut sehari-hari yang secara tidak langsung tanpa disadari telah memunculkan aturan-aturan internal dalam desa tersebut yang melibatkan banyak pihak mulai dari masyarakat di Desa Kalisat iru sendiri, pemuka agama setempat, dan sampai pihak masyarakat luar Desa Kalisat

${ }_{11}$ http://www.informasi-pendidikan.com/2013/08/Penelitian-deskriptif-kualitatif.html, diakses 24 November 2014.

${ }^{12}$ Lexi J. Moeloeng, Metodologi Penelitian Kualitatif, (Remaja Rosda Karya 2007).[6]. 
yang ingin melakukan praktik perkawinan sirri. Melalui pendekatan ini juga peneliti meneliti bagaimana aturan praktik perkawinan yang sesungguhnya diatur dalam aturan-aturan eksternal (hukum nasional) masyarakat Desa Kalisat, ditelaah dan dimaknai oleh masyarakatnya, sehingga hasil perjumpaan dari praktik perkawinan sirri dan perkawinan sesungguhnya dirumuskan untuk tujuan strategis masyarakat Desa Kalisat yang berbeda dari tujuan semula yang dimaksud oleh pembuat aturanaturan eksternal (hukum nasional).

\section{Lokasi Penelitian}

Penelitian dilakukan di Desa Kalisat, Kecamatan Rembang, Kabupaten Pasuruan, Jawa Timur. Desa Kalisat sendiri terbagi menjadi 5 dusun. Dusun-dusun tersebut antara lain Dusun Krajan, Dusun Budengan, Dusun Kedunglikit, Dusun Brukan, dan Dusun Barat Sungai. Dari 5 dusun yang ada, peneliti melakukan enelitian di suatu dusun yaitu Dusun Barat Sungai. Pemilihan dusun ini adaah didasarkan karena semua dusun yang ada di Desa Kalisat ini pada umumnya melakukan praktik perkawinan sirri, sehingga peneliti hanya mengambil satu dusun saja untuk dilakukan penelitian. Selain itu Dusun Barat Sungai merupakan dusun yang paling dekat dengan jalan utama sehingga perkawinan sirri tersebut cenderung lebih banyak dilakukan di daerah tersebut

\section{Subyek dan Obyek Penelitian}

Subyek penelitian adalah subyek yang dituju untuk diteliti oleh peneliti. Obyek peneliti adalah obyek yang dijadikan penelitian atau menjadi titik perhatian suatu penelitian. Dalam penelitian kali ini subyek peneliti adalah kepala dusun, pihak keamanan, dan penghulu yang berdomisili dan bermukim di Dusun Sungai Barat, Desa Kalisat, Kecamatan Rembang, Kabupaten Pasuruan. Sedangkan yang menjadi obyek penelitian adalah praktik mengenai perkawinan sirri yang dilakukan oleh warga pendatang dengan warga dari Dusun Sungai Barat, Desa Kalisat. 


\section{Teknik Pengumpulan Data}

Adalah cara yang digunakan peneliti untuk mendapatkan data dalam suatu penelitian. Penelitian kali ini, peneliti memilih jenis penelitian kualitatif sehingga data yang diperoleh haruslah mendalam, jelas dan spesifik. Pengumpulan data dapat diperoleh dari hasil observasi, wawancara, dokumentasi dan gabungan / triangulasi. ${ }^{13}$ Pada penelitian kali ini peneliti menggunakan teknik pengumpulan data dengan cara yang disebutkan diatas.

a. Observasi :

Adalah pengamatan yang dilakukan dengan sengaja dan sistematis terhadap aktivitas individu atau obyek lain yang diselidiki. ${ }^{14}$ Adapun jenis-jenis observasi adalah observasi terstruktur, observasi tidak terstruktur, observasi partisipan, dan observasi non partisipan. Dalam penelitian kali ini, peneliti menggunakan observasi terstruktur. Observasi terstruktur adalah observasi yang diselenggarakan dengan menentukan secara terstruktur faktor-faktor yang akan diobservasi lengkap dengan kategorinya. Dengan kata lain materi observasi telah dibatasi secara tegas sesuai dengan masalah dan tujuan penelitian.umumnya observasi terstruktur dilakukan dalam jangka waktu pendek. Oleh karena itu. Agar memperoleh data sebanyak mungkin dan lebih mempermudah penelitian, maka observasi ini memerlukan lebih dari seorang observer dan dilengkapi pula dengan penggunaan media elektronik dalam pengumpulan datanya.

b. Wawancara :

Teknik wawancara terbagi menjadi tiga : wawancara infrastruktur, wawancara semi terstruktur, dan wawancara mendalam (In depth interview) peneliti memilih teknik wawancara mendalam karena peneliti bertujuan untuk mengumpulkan informasi yang kompleks, yang sebagian besar berisi

\footnotetext{
${ }^{13}$ Sugiyono, Metode Kuantitatif, Kualitatif, dan $R \&$ D, (Alfabeta).[225].

${ }^{14}$ Kusuma A, Bahasa Indonesia: Buku Kerja, (Yasaguna 1987).[25].
} 
pendapat, sikap, dan pengalaman pribadi. ${ }^{15}$

c. Studi Pustaka :

Adalah teknik pengumpulan data yang dilakukan dengan mempelajari literatur acuan, laporan-laporan, majalah, jurnal, dan media lainnya yang berkaitan dengan obyek penelitian.

d. Dokumentasi :

Adalah catatan peristiwa yang telah berlaku. Dokumen yang digunakan peneliti adalah berupa foto, rekaman, dan data-data mengenai obyek penelitian. Hasil penelitian dari observasi dan wawancara akan semakin otentik dan dipercaya jika didukung oleh dokumentsi tersebut.

\section{Instrumen Penelitian}

Dalam penelitian kali ini, data yang diteliti adalah data yang berbentuk lisan maupun tulisan. Untuk mendapatkan data tersebut diperlukan alat bantu berupa media elektronik untuk mempermudah pengumpulan data. Untuk mempermudah pengumpulan data dari cara wawancara maka dibutuhkan Smartphone untuk merekam wawancara antara peneliti dengan narasumber. Untuk pengambilan gambar dan video peneliti menggunakan kamera DSLR hasil dari alat bantu media elektronik tersebut akan di transkripsikan melalui pencatatan sehingga memudahkan peneliti untuk pengumpulan data.

\section{Teknik Analisis Data}

Metode penelitian yang digunakan oleh peneliti adalah metodologi deskriptif kualitatif. Jadi, data yang diperoleh akan dianalisis secara kualitatif serta di uraikan dalam bentuk deskriptif. Analisis data adalah proses mengatur urutan data, mengorganisasikannya ke dalam suatu pola, kategori, dan uraian dasar. ${ }^{16}$ Definisi tersebut memberikan gambaran tentang pentingnya kedudukan analisa data dilihat

15 Sulistyo Basuki, Metode Penelitian, (Wedatama Widya Sastra \& Fakultas Ilmu Pengetahuan Budaya Universitas Indonesia 2006).[173].

${ }^{16}$ Lexi J. Moeloeng, Op.cit.[103]. 
dari segi tujuan penelitian. Prinsip pokok kualitatif adalah menemukan teori dari data. Teknik analisis data yang digunakan dalam penelitian ini adalah mennggunakan langkah-langkah pengumpulan data, reduksi data, display data, dan verifikasi serta penegasan kesimpulan. ${ }^{17}$ (Burhan Bungin, 2003 : 70)

a. Pengumpulan data

Pada penelitian ini menggunakan teknik observasi, wawancara, studi pustaka, dan dokumentasi.

b. Reduksi data

Adalah proses pemilihan, pemusatan perhatian pada penyederhanaan dan transformasi data kasar yang muncul dari catatan-catatan tertulis di lapangan.

c. Display data

Adalah pendeskripsian sekumpulan informasi tersusun yang memberikan kemungkinan adanya penarikan kesimpulan dan pengambilan tindakan. Penyajian data kualitatif disajikan dalam bentuk teks naratif.

d. Verifikasi dan Penegasan kesimpulan Penarikan kesimulan berupa kegiatan interpretasi, yaitu menemukan makna yang telah disajikan oleh data-data yang ada. Antara display data dengan penarikan kesimpulan terdapat analisis data yang ada. Data yang telah di analisis tersebut dijelaskan dan dimaknai dalam bentuk kata-kata untuk mendeskripsikan fakta yang ada di lapangan.

\section{Daftar Bacaan}

\section{Buku}

Burhan Bungin, Analisis Data Penelitian Kualitatif, Pemahaman Filosofis, dan Metodologis ke Arah Penguasaan Aplikasi, (Raja Grafindo Persada 2003).

Kusuma A, Bahasa Indonesia : Buku Kerja, (Yasaguna 1987).

Lexi J. Moeloeng, Metodologi Penelitian Kualitatif, (Remaja Rosda Karya 2007).

${ }^{17}$ Burhan Bungin, Analisis Data Penelitian Kualitatif, Pemahaman Filosofis, dan Metodologis ke Arah Penguasaan Aplikasi, (Raja Grafindo Persada 2003),[70]. 
Martiman Prodjohamidjojo, Hukum Perkawinan dalam Tanya Jawab, (Legal Center Publishing 2007).

Martiman Prodjohamidjojo, Hukum Perkawinan Indonesia, (Legal Center Publishing 2007).

Sugiyono, Metode Kuantitatif, Kualitatif, dan $R \& D$, (Alfabeta).

Sulistyo Basuki, Metode Penelitian, (Wedatama Widya Sastra \& Fakultas Ilmu Pengetahuan Budaya Universitas Indonesia 2006).

Sayuti Thalib, Hukum Kekeluargaan Indonesia, (Internas 1981).

\section{Laman}

Http://nasional.inilah.com/read/detail/1839431/inilah-perempuan-enam-kalinikah-sirri\#.VHBkyvmUdDa, diakses pada22 November 2014.

http ://www.albayyinat.net/mutaht.html, diakses pada 22 November 2014.

http: //www.hukumonline.com/berita/baca/holl5650/kawin-kontrak-antara-agamahukum-dan-realita, diakses pada 22 November 2014.

http://www.informasi-pendidikan.com/2013/08/Penelitian-deskriptif-kualitatif. html, diakses 24 November 2014

HOW TO CITE: Avisena Aulia Anita, Felisa Haryati dan Diah Astri Ellisa, 'Perkawinan Sirri Di Desa Kalisat Kecamatan Rembang Kabupaten Pasuruan' (2018) Vol. 1 No. 2 Notaire. 